\title{
Methanoculleus bourgensis, Methanoculleus olentangyi and Methanoculleus oldenburgensis are subjective synonyms
}

\author{
Susumu Asakawat and Kazunari Nagaokał \\ Laboratory of Soil Microbiology, Kyushu National Agricultural Experiment Station, Nishigoshi, \\ Kumamoto 861-1192, Japan
}

Correspondence

Susumu Asakawa

asakawa@agr.nagoya-u.ac.jp

\begin{abstract}
Methanoculleus bourgensis, Methanoculleus olentangyi and Methanoculleus oldenburgensis are subjective synonyms on the basis of phenotypic, genotypic and phylogenetic characteristics. Methanoculleus bourgensis must be the name of the united species because it is the type of the genus Methanoculleus.
\end{abstract}

The genus Methanoculleus currently includes seven species: Methanoculleus marisnigri, Methanoculleus bourgensis, Methanoculleus thermophilus, Methanoculleus olentangyi, Methanoculleus oldenburgensis, Methanoculleus palmolei and Methanoculleus chikugoensis (Maestrojuán et al., 1990; Romesser et al., 1979; Ollivier et al., 1986; Rivard \& Smith, 1982; Corder et al., 1983; Blotevogel et al., 1991; Zellner et al., 1998; Dianou et al., 2001). In the course of the identification of Methanoculleus chikugoensis $\mathrm{MG62}^{\mathrm{T}}$ (Dianou et al., 2001), a DNA-DNA hybridization study revealed that Methanoculleus bourgensis $\mathrm{MS}^{\mathrm{T}}{ }^{\mathrm{T}}$, Methanoculleus olentangyi $\mathrm{RC} / \mathrm{ER}^{\mathrm{T}}$ and Methanoculleus oldenburgensis CB- ${ }^{\mathrm{T}}$ were genomically closely related (67-104\% relatedness to each other), though a similar close relatedness (66\%) between Methanoculleus bourgensis and Methanoculleus olentangyi had already been reported by Xun et al. (1989). We supplemented these results by examining some genotypic and phylogenetic features of the type strains and we now confirm the synonymy of these three species on the basis of these features and phenotypic characteristics already reported.

The 16S rDNA sequence of Methanoculleus oldenburgensis was determined, since it had not previously been available. The type strain, CB- $1^{\mathrm{T}}$ (=DSM $\left.6216^{\mathrm{T}}\right)$, was obtained from the Deutsche Sammlung von Mikroorganismen und Zellkulturen (DSMZ), Braunschweig, Germany. Methods for DNA isolation, PCR amplification and sequencing of $16 \mathrm{~S}$ rDNA were the same as described previously (Dianou et al.,

Published online ahead of print on 28 March 2003 as DOI 10.1099/ ijs.0.02508-0.

tPresent address: Soil Biology and Chemistry, Graduate School of Bioagricultural Sciences, Nagoya University, Chikusa, Nagoya 4648601, Japan.

‡Present address: National Agricultural Research Center, Tsukuba 305-8666, Japan.

The DDBJ/GenBank/EMBL accession number for the $16 \mathrm{~S}$ rDNA sequence of Methanoculleus oldenburgensis $\mathrm{CB}-1^{\top}$ is AB065298.
2001). The sequence similarities of strain CB- $1^{\mathrm{T}}$ to Methanoculleus bourgensis $\mathrm{MS}^{\mathrm{T}}$ and Methanoculleus olentangyi RC/ $\mathrm{ER}^{\mathrm{T}}$ and between strains $\mathrm{MS} 2^{\mathrm{T}}$ and $\mathrm{RC} / \mathrm{ER}^{\mathrm{T}}$ were respectively $97 \cdot 1,98 \cdot 7$ and $97 \cdot 7 \%$, which was consistent with the DNA-DNA hybridization results mentioned above (Dianou et al., 2001).

These three strains seem to have almost the same phenotypic features: the cells are 1-2 $\mu \mathrm{m}$ in diameter, flagellation and motility are not observed (fimbriae-like structures have been reported in the case of Methanoculleus oldenburgensis CB- ${ }^{\mathrm{T}}$ cells), $\mathrm{H}_{2} / \mathrm{CO}_{2}$ and formate are used as methanogenic substrates (some secondary alcohols are also used by Methanoculleus bourgensis $\mathrm{MS}^{\mathrm{T}}$ and Methanoculleus olentangyi $\mathrm{RC} / \mathrm{ER}^{\mathrm{T}}$ ), acetate is required for growth and the optimum temperature, $\mathrm{pH}$ and $\mathrm{NaCl}$ concentration for growth are respectively about $40{ }^{\circ} \mathrm{C}\left(37-45^{\circ} \mathrm{C}\right)$, near neutral $(6 \cdot 7-8 \cdot 0)$ and about $0 \cdot 1 \mathrm{M}(0 \cdot 04-0 \cdot 17 \mathrm{M})$ (Blotevogel et al., 1991; Ollivier et al., 1986; Corder et al.,1983; Maestrojuán et al., 1990; Zellner et al., 1990; Chong \& Boone, 2001; see also Table 2 of Dianou et al., 2001). Some resemblances of whole-cell protein electrophoretic patterns, S-layer structures and polyamine compositions between Methanoculleus bourgensis $\mathrm{MS}^{\mathrm{T}}$ and Methanoculleus olentangyi $\mathrm{RC} / \mathrm{ER}^{\mathrm{T}}$ were also reported (Maestrojuán et al., 1990; Zellner et al., 1990).

The sole differentiating characteristic is the $\mathrm{G}+\mathrm{C}$ content of DNA. The $\mathrm{G}+\mathrm{C}$ contents of Methanoculleus bourgensis $\mathrm{MS}^{\mathrm{T}}$, Methanoculleus olentangyi RC/ER ${ }^{\mathrm{T}}$ and Methanoculleus oldenburgensis $\mathrm{CB}-1^{\mathrm{T}}$ were respectively originally reported to be $59,54 \cdot 4$ and $48 \cdot 6 \mathrm{~mol} \%$, the first two being determined by the buoyant density method and the latter by thermal denaturation. The range is $10 \mathrm{~mol} \%$, which seems too large for members of a single species. Therefore, we measured the $\mathrm{G}+\mathrm{C}$ contents of DNA from these three strains by the same method (HPLC), as described previously (Dianou et al., 2001), using a Hitachi 683-50 HPLC system. The values for Methanoculleus bourgensis $\mathrm{MS}^{\mathrm{T}}$, Methanoculleus 
olentangyi $\mathrm{RC} / \mathrm{ER}^{\mathrm{T}}$ and Methanoculleus oldenburgensis CB- $1^{\mathrm{T}}$ were respectively $60 \cdot 5 \pm 0 \cdot 0,61 \cdot 1 \pm 0 \cdot 3$ and $60 \cdot 2 \pm$ $0 \cdot 2$ mol\% (mean \pm SD, $n=3$ ).

The similarities of phenotypic, genotypic and phylogenetic characteristics described above indicate that Methanoculleus bourgensis (Ollivier et al. 1986) Maestrojuán et al. 1990, Methanoculleus olentangyi (Corder et al. 1988) Maestrojuán et al. 1990 and Methanoculleus oldenburgensis Blotevogel et al. 1998 are subjective synonyms. Rule 15 of the Bacteriological Code (Lapage et al., 1992) indicates that the type of a taxon is permanently associated with that taxon; therefore, since Methanoculleus bourgensis is the type of the genus Methanoculleus Maestrojuán et al. 1990, the name Methanoculleus bourgensis must be retained for the united species.

The physiological variance of strain CB-1, such as its slightly higher temperature for optimum growth, might indicate its affiliation to a subspecies within the united species. However, further information concerning the phenotypic characters of strain CB-1 and the other strains will be needed for the taxonomic description of strain CB-1.

\section{Emended description of Methanoculleus bourgensis (Ollivier et al. 1986) Maestrojuán et al. 1990}

The descriptions of the genus Methanoculleus and the species Methanoculleus bourgensis have been given by Maestrojuán et al. (1990). Strains RC/ER and CB-1, previously the type strains of Methanoculleus olentangyi and Methanoculleus oldenburgensis, respectively, are reference strains of the species Methanoculleus bourgensis. The type strain is strain $\operatorname{MS}^{\mathrm{T}}\left(=\operatorname{ATCC} 43281^{\mathrm{T}}=\operatorname{DSM} 3045^{\mathrm{T}}\right)$.

\section{Acknowledgements}

We thank Y. Koga of the University of Occupational and Environmental Health, Japan, Y. Kamagata of the National Institute of Advanced Industrial Sciences and Technology and T. Ito of the Japan Collection of Microorganisms, RIKEN, for their helpful advice and Y. Hamahira of Hitachi Instruments Service Co., Ltd for his help in operating the HPLC apparatus.

\section{References}

Blotevogel, K.-H., Gahl-Janßen, R., Jannsen, S., Fischer, U., Pilz, F., Auling, G., Macario, A. J. L. \& Tindall, B. J. (1991). Isolation and characterization of a novel mesophilic, fresh-water methanogen from river sediment Methanoculleus oldenburgensis sp. nov. Arch Microbiol 157, 54-59.
Chong, S. C. \& Boone, D. R. (2001). Genus II. Methanoculleus Maestrojuán, Boone, Xun, Mah and Zhang 1990, $121^{\mathrm{VP}}$. In Bergey's Manual of Systematic Bacteriology, 2nd edn, vol. 1 (The Archaea and the Deeply Branching and Phototrophic Bacteria), pp. 251-252. Edited by D. R. Boone, R. W. Castenholz \& G. M. Garrity. New York: Springer.

Corder, R. E., Hook, L. A., Larkin, J. M. \& Frea, J. I. (1983). Isolation and characterization of two new methane-producing cocci: Methanogenium olentangyi, sp. nov., and Methanococcus deltae, sp. nov. Arch Microbiol 134, 28-32.

Corder, R. E., Hook, L. A., Larkin, J. M. \& Frea, J. I. (1988). Methanogenium olentangyi sp. nov. In Validation of the Publication of New Names and New Combinations Previously Effectively Published Outside the IJSB, List no. 25. Int J Syst Bacteriol 38, 220-222.

Dianou, D., Miyaki, T., Asakawa, S., Morii, H., Nagaoka, K., Oyaizu, H. \& Matsumoto, S. (2001). Methanoculleus chikugoensis sp. nov., a novel methanogenic archaeon isolated from paddy field soil in Japan, and DNA-DNA hybridization among Methanoculleus species. Int J Syst Evol Microbiol 51, 1663-1669.

Lapage, S. P., Sneath, P. H. A., Lessel, E. F., Skerman, V. B. D., Seeliger, H. P. R. \& Clark, W. A. (editors) (1992). International Code of Nomenclature of Bacteria (1990 Revision). Bacteriological Code. Washington, DC: American Society for Microbiology.

Maestrojuán, G. M., Boone, D. R., Xun, L., Mah, R. A. \& Zhang, L. (1990). Transfer of Methanogenium bourgense, Methanogenium marisnigri, Methanogenium olentangyi, and Methanogenium thermophilicum to the genus Methanoculleus gen. nov., emendation of Methanoculleus marisnigri and Methanogenium, and description of new strains of Methanoculleus bourgense and Methanoculleus marisnigri. Int J Syst Bacteriol 40, 117-122.

Ollivier, B. M., Mah, R. A., Garcia, J. L. \& Boone, D. R. (1986). Isolation and characterization of Methanogenium bourgense sp. nov. Int J Syst Bacteriol 36, 297-301.

Rivard, C. J. \& Smith, P. H. (1982). Isolation and characterization of a thermophilic marine methanogenic bacterium, Methanogenium thermophilicum sp. nov. Int J Syst Bacteriol 32, 430-436.

Romesser, J. A., Wolfe, R. S., Mayer, F., Spiess, E. \& WaltherMauruschat, A. (1979). Methanogenium, a new genus of marine methanogenic bacteria, and characterization of Methanogenium cariaci sp. nov. and Methanogenium marisnigri sp. nov. Arch Microbiol 121, 147-153.

Xun, L., Boone, D. R. \& Mah, R. A. (1989). Deoxyribonucleic acid hybridization study of Methanogenium and Methanocorpusculum species, emendation of the genus Methanocorpusculum, and transfer of Methanogenium aggregans to the genus Methanocorpusculum as Methanocorpusculum aggregans comb. nov. Int J Syst Bacteriol 39, 109-111.

Zellner, G., Sleytr, U. B., Messner, P., Kneifel, H. \& Winter, J. (1990). Methanogenium liminatans spec. nov., a new coccoid, mesophilic methanogen able to oxidize secondary alcohols. Arch Microbiol 153, 287-293.

Zellner, G., Messner, P., Winter, J. \& Stackebrandt, E. (1998). Methanoculleus palmolei sp. nov., an irregularly coccoid methanogen from an anaerobic digester treating wastewater of a palm oil plant in North-Sumatra, Indonesia. Int J Syst Bacteriol 48, 1111-1117. 